Jurnal Jeumpa, 7 (2) Juli-Desember 2020

\title{
PENERAPAN MEDIA KOTAK DAN KARTU MISTERIUS (KOKAMI) UNTUK MENINGKATKAN HASIL BELAJAR SISWA PADA MATERI MAKANAN DAN SISTEM PENCERNAAN KELAS XI SMA N 2 KEJURUAN MUDA TAHUN PELAJARAN 2018/2019
}

\author{
Tiara Mustika ${ }^{1}$ Sofian $^{2}$, Tri Mustika sarjani ${ }^{3}$ \\ Prodi Pendidikan Biologi Fakultas Keguruan Dan Ilmu Pendidikan \\ Universitas Samudra \\ Email : tiaramustika1995@gmail.com
}

\begin{abstract}
ABSTRAK
Berdasarkan obsevasi awal di SMA 2 karang baru di bulan vovember 2017 diketahui bahwasanya penggunaan media pembelajaran mesih tergolong sedikit sehinnga belajar cenderung perpusat pada guru. Selain itu murid yang pintar menjadi mendominasi secara aktif, sedangkan murid yang kurang pintar umumnya akan pasif dalam belajar. Salah satu media pembelajaran yang dapat diterapkan adalah media kokami. Tujuannya untuk mengetahui penerapan media kotak dan kartu misterius (kokami) dan meningkatkan hasil belajar siswa pada materi makanan dan sistem pencernaan kelas XI SMA 2 Kejuruan Muda tahun pelajaran 2018/2019. Metode penelitian berupa eksperimen, sedangkan sampel 1 yaitu kelompok eksperimen menggunakan media kokami untuk menghitung hasil belajar. Dari hasil penelitian yang telah didapatkan maka penulis mengambil kesimpulan sebagai berikut: Ada peningkatan Penerapan Media Kotak dan Kartu Misterius (KOKAMI) Untuk Meningkatkan Hasil Belajar Siswa, hal ini dapat dilihat dari nilai t hitung lebih besar dari pada $t$ tabel yaitu sebesar 4,62 yang diketahui nilai $t_{\text {hitung }}$ yang diperoleh adalah 4,62 sedangkan nilai tabel yang diperoleh adalah 2,012 sehingga karena $t_{\text {hitung }} \geq t_{\text {tabel }}$, yaitu 4,62 $\geq 2,012$ pada taraf signifikan $\alpha=0,05$ maka $H_{o}$ ditolak $H_{a}$ diterima dan dapat disimpulkan bahwa Ada peningkatan Penerapan Media Kotak dan Kartu Misterius (KOKAMI) Untuk Meningkatkan Hasil Belajar Siswa Pada Materi Makanan dan Sistem Pencernaan Makanan Kelas XI SMA Negeri 2 Kejuruan Muda Tahun Pelajaran 2018/2019.
\end{abstract}

Kata kunci : media, kotak dan kartu misterius (kokami), hasil belajar, dan peningkatan

\section{ABSTRACT}

Based on initial observations at SMA 2 Karang Baru in November 2017, it is known that the use of learning media is still relatively small so that learning tends to be teacher-centered. In addition, students who are smart become actively dominate, while students who are less smart generally will be passive in learning. One of the learning media that can be applied is kokami media. The goal is to find out the application of mysterious box and card media (kokami) and improve student learning outcomes in food material and the digestive system of class XI SMA 2 Young Vocational School 2018/2019 academic year. The research method is in the form of an experiment, while sample 1 is the experimental group using kokami media to calculate learning outcomes. From the results of the research that has been obtained, the authors draw the following conclusions: There 
is an increase in the Application of Mysterious Box and Card Media (KOKAMI) to Improve Student Learning Outcomes, this can be seen from the $t$ value is greater than the table which is equal to 4.62 which It is known that the value of $t$ count obtained is 4.62 while the table value

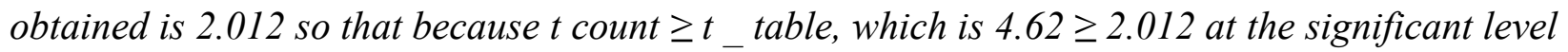
$\alpha=0.05$ then $H \_o$ is rejected, $H \_a$ is accepted and it can be concluded that there is an increase Application of Mysterious Media Boxes and Cards (KOKAMI) to Improve Student Learning Outcomes in Food Materials and the Digestive System for Class XI SMA Negeri 2 Young Vocational High School 2018/2019 Academic Year.

Keywords: media, mysterious boxes and cards (kokami), learning outcomes, and improvement

\section{PENDAHULUAN}

Pendidikan merupakan pondasi utama dalam membangun kehidupan bangsa. Menurut (triwiyanto, 2014:22) pendidikan "segala pengaruh yang di upayahkan sekolah terhadap anak adan remaja yang diserahkan kepadanya agar mempunyai kemampuan yang sempurna dan kesadaran penuh terhadap hubungan dan tugas sosial mereka”. Seharusnya hasil dari pendidikan yang diberikan oleh siswa dapat membawa perubahan yang lebih baik dimasa mendatang baik dalam pengetahuan, sikap serta keterampilan dimasyarakat. Maka diperlukan strategi pendidikan yang menjadi saran untuk membuka gagasan peserta didik bahwa ilmu yang mereka pelajari memiliki substansi hidup sehingga ilmu tersebut mampu mengubah sikap, pengetahuan dan keterampilan menjadi lebih baik.

Pembelajaran merupakan suatu sistem yang memiliki peran sangat dominan untuk mewujudkan kualitas pendidikan.
Menurut (Wardhana, 2010: 47) “dalam keanearagaman media belajar dan mengajar tersebut, seorang guru harus pandai pandai memilih media mana yang paling efektif untuk menyampaikan pesan”. (Martin, 2013:77) menjelaskan "gagasan inovatif dalam metode mengajar misalnya, selalu didasarkan kepada pengadaan pembelajaran yang lebih efektif dan efisisen". Berdasarkan gagasan diatas diperlukan media yang sanggup menyertakan siswa secara menyeluruh sehingga belajar mengajar tidak hanya didominasi oleh siswa tertentu saja. Pemilihan model pembelajaran diharapkan dapat meningkatkan hasil nilai dalam menelaah ilmu.

Berdasarkan observasi awal di SMA Negeri 2 Karang Baru dibulan November 2017 diketahui bahwasanya penggunaan media pembelajaran masih tergolong sedikit sehingga sistem belajar cenderung berpusat pada guru. Selain itu murid yang pintar menjadi mendominasi pembelajaran secara aktif, sedangkan murid yang kurang pintar 
Jurnal Jeumpa, 7 (2) Juli-Desember 2020

umumnya akan pasif dalam belajar. media yang cocok untuk diterapkan adalah media KOKAMI.

Menurut (sukiman, 2012:44) "media kokami (kotak dan kartu misterius) yang dikombonasikan denga permainan. Penerepannya melibatkan seluruh siswa, baik yang pasif maupun yang aktif". Dengan demikian (Santi, 2010: 2) mengatakan "kokami adalah salah satu jenis media yang dikombinasikan dengan permainan bahasa. Penerapannya melibatkan seluruh siswa, baik siswa yang biasanya pasif maupun yang aktif. Dengan demikian, permainan ini sangat baik digunakan dalam kelas yang heterogen". Gabungan antara belajar dan permainan mampu secara signifikan memberikan motivasi dan menarik minat siswa. Untuk terlibat dalam proses pembelajaran media KOKAMI (kotak dan kartu misterius) memiliki beberapa peraturan menurut (Santoso, 2012: 6) yaitu:

a. Setiap kelompok terdiri dari 6-8 siswa yang duduk mengarah ke papan tulis yang sudah disiap kan tabel skor oleh beserta alat tulis yang sudah rapi di meja.

b. Guru dan siswa melantik ketua dari setiap kelompok.

c. Semas permainan, ketua dibantu sepenuhnya oleh anggota. d. Tugas ketua mengambil satu amplop di kotak misterius secara acak dan tidak dibenarakan untuk melihat.

e. Setiap anggota diwajibkan menyelesaikan pekerjaannya.

f. Bila kelompok satu tidak bisa menyelesaiakan tugasnya maka kelompok lain berhak mengambil aloh tugasnya

g. Grup yang mendapatkan nilai tertinggi akan menjadi pemenang dan akan mendapatkan hadia

h. Kelompok yang memiliki skor rendah akan mendapatkan hukumannya

Menurut (martin, 2013:78) 'Peningkatan hasil belajar ialah sesuatu yang telah dicapai siswa dalam melakukan usaha (belajar)". Dapat di artikan sebagai suatu keberhasilan stelah mengikuti pelajaran seharian penuh. Adapun tujuan yang diinginkan adalah untuk mengetahui penerapan media kotak dan kartu miterius (kokami) untuk meningkatkan hasil belajar siswa dan untuk mengetahui seberapa besar peningkatan hasil belajar siswa pada materi makana dan sistem pencernaan kelas XI SMA N 2 Kejuruan Muda tahun pelajaran 2018/2019. 


\section{METODELOGI PENELITIAN}

\section{Waktu Dan Tempat}

waktu penelitian ini direncankan bulan agustus 2018 bertepatan di SMA N 2 Kejuruan Muda.

\section{Metode Dan Variabel}

metode yang digunakan adalah metode eksperimen, objek dibagi menjadi satu kelompok atau satu kelas, adapun yang menjadi variabelnya yaitu peningkatan hasil belajar siswa.

\section{Populasi Dan Sampel}

populasinya seluruh siswa kelas XI SMA 2 terdiri dari 6 kelas dengan jumlah 189 siwa. Sampel dalam penelitian yaitu kelas XI-IPA 2 yang berjumlah 34 siswa dengan menggunakn metode simple radom sampling data populasi siswa dilihat pada tabel 1.

Tabel 1 : Data Populasi Dan Sampel Siwa

Kelas XI SMA N2 Kejuruan Muda

\begin{tabular}{|c|c|}
\hline Kelas & Jumlah \\
\hline XI-IPA1 & 28 \\
\hline XI-IPA2 & 34 \\
\hline XI-IPA3 & 32 \\
\hline XI-IPA4 & 32 \\
\hline XI-IPA5 & 30 \\
\hline XI-IPA6 & 33 \\
\hline JUMLAH & $\mathbf{1 8 9}$ \\
\hline
\end{tabular}

(Suber Data: Tata Usaha SMA N 2 Kejuruan Muda )

\section{Uji Intrumen}

Alat untuk penelitian ini adalah tes tulis berupa pretes dan postes pilihan ganda dengan jumlah 25 soal untuk diuji validitas terlebih dahulu.

\section{HASIL DAN PEMBAHSAN}

Berdasarkan hasil observasi dapat diketahui bahwa Ada peningkatan hasil diterima siswa dengan menggunakan media kotak dan kartu misterius (KOKAMI) Materi Makanan dan Sistem Pencernaan Makanan Kelas XI SMA Negeri 2 Kejuruan Muda Tahun Pelajaran 2018/2019. Maka hasil yang saya dapatkan yaitu $t_{\text {hitung }} \geq t_{\text {tabel }}$, yaitu $4,62 \geq 2,012$ pada taraf signifikan $\alpha=0,05$ maka $H_{o}$ ditolak $H_{a}$ diterima dan dapat disimpulkan bahwa Ada peningkatan Penerapan Media Kotak dan Kartu Misterius (KOKAMI) Meningkatkan Hasil Belajar Siswa Pada Materi Makanan dan Sistem Pencernaan Makanan Kelas XI SMA Negeri 2 Kejuruan Muda Tahun Pelajaran 2018/2019.

Pada berbagai macam kiteria tersebut maka saya mendapatkan kiteria "baik" dari hasil penelitian dengan media kotak dan kartu misterius (KOKAMI). Hal ini disebabkan karena media kotak dan kartu misterius (KOKAMI) yang telah digunakan pada proses pembelajaran menarik perhatian 
siswa. Dalam proses belajar mengajar ketua kelompok saja yang mengambil kartu yang berisi berbagai macam pertanyaan sedangkan siswa yang lain juga ingin mengambil kartu berisis pertanyaan tersebut, maka dari itu hasil yang saya dapat dari penelitian ini baik.

Sebelum saya menerapkan sistem belajar dengan menggunakan media kotak dan kartu misterius (KOKAMI) nilai rata-rata siswa sebesar 46,26. Nilai tersebut didapat dari nilai pretes siswa. Setelah saya menerapkan sistem belajar dengan menggunakan media kotak dan kartu misterius (KOKAMI) nilai rata-rata siswa menjadi meningkat yaitu sebesar 77,02. Nilai tersebut didapat dari hasil postes. Selisih nilai rata-rata yang telah didapat dari nilai pretes dan postes yaitu sebesar 30,76.

Menurut (Sadiman, 2010:45) menjelaskan "Pemanfaatan media dalam belajar dapat membangkitkan minat baru, dan motivasi belajar secara psikologis kepada siswa". (Usman, 2012:11) "media pembelajaran sesuatu yang bersifat menyalurkan pesan pikiran, perasaan, dan kemauan siswa sehingga dapat mendorong terjadinya proses belajar pada dirinya". Pembelajaran adalah hubungan antara guru dan murid dengan berbagai aktivitas yang bertujuan mengubah kepribadian peserta didik yang pada dasarnya sangat rumit. Tetapi memiliki pesan yang meliputi pengetahuan, nilai dan keterampilan peserta didik. secara bertahap untuk memahami inti dari pembelajaran.

\section{DAFTAR PUSTAKA}

Martin. (2013). Dasar-Dasar Perencanaan Pendidikan. Jakarta: Rajawali Pers.

Santi (2010). Efektivitas Penggunaan media Pembelajaran KOKAMI terhadap Hasil Belajar IPA pada Materi Pokok Daur Hidup Beberapa Hewan Peserta Didik Kelas IV Madrasah Ibtidaiyah Bahrul Ulum balen Bojonegoro.Jurnal Pendidikan. Jurusan PGMI, Fakultas Tarbiyah Institut Agama Islam Negeri (IAIN) Walisongo Semarang.

Santoso. (2012). Penerapan Media Pembelajaran KOKAMI di sekolah. Jurnal Pendidikan, FKIP Unsri. Riau

Sadiman, Arief. S dkk. (2010). Media Pendidikan, Pengertian, Pengembangan dan Pemanfaatannya. Jakarta: Rajawali Pers.

Sukiman. (2012). Pengembangan Media Pembelajaran. Yogyakarta: Pustaka Insan Madani

Triwiyanto. (2014). Pengantar Pendidikan. Jakarta: Bumi Aksara.

Usman (2012). Media Pembelajaran. Jakarta: Citra Utama

Wardhana. 2010. Teori Belajar Dan Mengajar. Bandung: Pribumi Mekar 